\title{
: A ESCRITA COMO ÁGUA VIVA
}

\author{
Telma Scherer* \\ Universidade Federal de Santa Catarina
}

\begin{abstract}
Resumo: Neste artigo farei uma leitura da novela Água viva, de Clarice Lispector, a partir das considerações de Helène Cixous sobre o processo criativo, presentes no livro Three steps on the ladder of writing. Cixous compõe a imagem de uma escada descendente com três degraus: o da morte, o dos sonhos e o das raízes. Lispector empreende esse caminho em busca do "it", exercício investigativo que é também uma prática radical com as palavras. A fim de seguir o percurso descendente e investigar o "it" através de leituras comparadas, trarei para a análise poemas de Hilda Hilst, do livro Poemas malditos, gozozos e devotos e também de Sylvia Plath, em Ariel, nomeadamente o poema "Lady Lazarus". Hilst empreende um jogo entre obediência e subversão, fé e criação poética, propondo uma complexidade de imagens a partir da ideia de Deus, transfigurada. Já Plath traz para a reflexão a recorrência cíclica que é também abandono de todo medo. As leituras de Hilst e Plath iluminam, a seu modo, o percurso empreendido no rastro de Cixous e enriquecem o roteiro de busca do "it" clariceano. Palavras chave: Lispector. Cixous. Poesia. Criação. Morte.
\end{abstract}

\section{Introdução}

Este texto procura desenvolver uma leitura de Água viva, de Clarice Lispector, a partir das propostas de Helène Cixous em Three steps on the ladder of writing, um conjunto de textos nos quais ela procura desenvolver uma apreciação do processo criativo a partir da imagem de uma escada descendente. ${ }^{1}$ Desejo seguir os ecos de Helène Cixous em sua escada da escritura, escada que descende para as profundezas, cruzando as bordas (elas existem?) que separam o puro e o impuro, a regra e o prazer, o adequado e a aventura. Quero encontrar uma poética do limite a partir da asserção de que escrever é uma forma de existir sem garantias. Perfazer esse percurso de tessituras curvilíneas, tensas, lindas, encontrando propostas que entre si colaboram para o movimento da escada.

O texto de Helène Cixous em que me apoio é um exemplo híbrido e pulsante, no qual

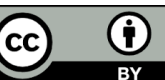

Esta obra está licenciada sob uma Creative Commons - Atribuição 4.0

\footnotetext{
* Doutora em Teoria Literária pela UFSC e integra o LabFLOR - Laboratório Floripa em Composição Transdisciplinar: Arte, Cultura e Política. E-mail: <rumordacasa@gmail.com>.

${ }^{1}$ A ideia inicial deste artigo surgiu a partir de um curso ministrado pela Dr ${ }^{\mathrm{a}}$ Tereza Virginia de Almeida no Programa de Pós-Graduação em Literatura da Universidade Federal de Santa Catarina em 2012 com o título "Entre poetas e loucas: por uma genealogia clariceana para a poética do limite". A primeira versão do texto, em forma de monografia, recebeu os comentários da professora Tereza Virginia, a quem agradeço pela motivação e pelas sugestões.
}

Anu. Lit., Florianópolis, v. 21, n. 2, p. 118-133, 2016. ISSNe 2175-7917 
a teoria, a crítica, o depoimento e a autobiografia se harmonizam em torno da pergunta pelo ato de escrever; a busca é colocada em termos de experiência criativa, não como um objeto separado. O livro canta enquanto teoriza, e a leitura que fiz dele cantará junto com os criadores escolhidos.

Inicio neste trecho de Clarice Lispector:

Então escrever é o modo de quem tem a palavra como isca: a palavra pescando o que não é palavra. Quando essa não-palavra - a entrelinha - morde a isca, alguma coisa se escreveu. Uma vez que se pescou a entrelinha, poder-se-ia com alívio jogar a palavra fora. Mas aí cessa a analogia: a não-palavra, ao morder a isca, incorporoua. O que salva então é escrever distraidamente.

Não quero ter a terrível limitação de quem vive apenas do que é passível de fazer sentido. Eu não: quero é uma verdade inventada. (LISPECTOR, 1998a, p. 20)

É impossível capturar a entrelinha fora da forma: ela está atrelada à palavra, incorporada de maneira indissociável. O processo criativo tem de ser entendido também de dentro, na imbricação de leituras e escrituras íntimas, num texto que soma ao texto, sendo texto, sem isenção. Da mesma forma, a leitura se contamina com o fazer; a crítica se faz fazendo: os textos literários e a teoria estão tão acoplados quanto a entrelinha à palavra. É nesse entendimento de inseparabilidade e comunhão que se dá a minha leitura da poética clariceana calcada em Cixous. (Outra via possível a interpretaria de fora, no contexto de uma linha teórica fechada, com a sustentação de uma filosofia particular, de um conjunto de dogmas; porém aí o processo criativo da poética do limite estaria encarcerado, o que afastaria em definitivo a abordagem de Cixous, e é na trilha dos Three steps on the ladder of writing ${ }^{2}$ que construirei minha leitura.)

Cixous elenca um grupo de escritores, seus preferidos; utiliza-os como exemplos do que ela pretende ensinar nas suas três lições a respeito do escrever, três degraus descendentes de uma escada: o primeiro, dos Mortos, define a entrada no mundo subversivo, quase proibido, da criação. O segundo é o degrau dos Sonhos e para alcançá-los é necessária uma técnica e cuidado especiais, já que é característica dos sonhos evadir-se. O terceiro degrau, das Raízes, imiscui-nos nas profundezas desse universo tão próximo da terra quanto do inconsciente, com suas ressonâncias de poesia e de perversão, e que deverá acabar nas flores. Nesse percurso, Cixous pronuncia sua adesão a um esquema conceitual onde limite e cruzamento de fronteiras desempenham funções imprescindíveis.

A verdade inventada tem de extrapolar as barreiras de um fazer-sentido comezinho, arriscar-se para fora do uso cotidiano, lucrativo, da linguagem. Em busca do não-sentido,

\footnotetext{
${ }^{2}$ Tradução do original francês de Sarah Cornell e Susan Sellers. CIXOUS, Helène. Three steps on the ladder of writing. Columbia University Press, 1993.
} 
Clarice desafia a lógica vigente, o adequado, que Helène Cixous descreve como "Those-HeBible" e "Those-Bible": um "eles" relacionado à norma e à convenção. Cixous segue a sugestão escrita em A paixão segundo GH (LISPECTOR, 1988b) de um "eles”, os que "explicam tudo" sem explicar; ela então os aponta como aqueles que normatizam, superficializam, proíbem a aventura. Para Silviano Santiago, por sua vez, a literatura de Clarice "é um rio que inaugura o seu próprio curso" (SANTIAGO, 2008, p. 232). Essa escrita pode ser lida como uma "experiência de mundo inaugural", segundo a pesquisadora Lucia Castello Branco, que parte de Lacan para afirmar que o ponto da escritura clariceana é um "ponto de p", que procura criar inícios, sendo o ser humano já nascido no meio (BRANCO, 1998, p. 33).

A referência ao Levítico e suas prescrições é alavanca no texto de Cixous: quando a Bíblia afirma o limite do que pode e do que não pode ser feito, dos animais que podemos e não podemos comer, conceitualizando o "abominável" e "imundo", cria a marginalização de uma forma de compreender a vida simbolizada pelos pássaros, as mulheres, os poetas. ThoseBible é uma categoria de pessoas, também a mentalidade hegemônica e a autoria da transgressão, pois é necessário atravessar os seus limites para que seja possível usufruir daquilo que, para Cixous, é o melhor.

Se o aprendiz, o leitor, o teórico não ousarem desafiar o que Those-Bible obedecem, serão privados da experiência central, que Clarice denomina inferno e Genet domaines inférieures. É um inferno de delícias que se mostra como processo criativo e está para além dos julgamentos morais, objeto de todo o labor de Cixous na construção de sua escada. Clarice segue-o em Água viva através de um percurso em busca do it, essa pura coisa, esse instante fugaz e indeterminável, isso que nos escapa sempre que pretendermos agarrá-lo. A pintora-narradora, familiarizada com as imagens de cavernas e todo mistério aquoso, rochoso e circunspeto que nelas mora, faz o puro improviso com as palavras, arrisca-se a cruzar as fronteiras entre linguagens para manifestar o it. Seu depoimento é rico de reflexões sobre esse desafio do uso das palavras. Nos vários trechos de Água viva que iluminam meu caminho aqui, além do supracitado, encontro a analogia entre o processo a que se propõe a narradora e o mistério da criação artística, aqui flagrado com a beleza da metáfora e em seu dinamismo.

“Este não é um livro porque não é assim que se escreve” (LISPECTOR, 1998a, p. 11-12). A fim de chegar ao tom do que se busca na seara desejada, é preciso cruzar a barreira do livro, escrever um não-livro, livrar-se das regras que delimitam o adequado. É preciso não dar atenção a Those-Bible e, como Genet lido por Cixous, viver o perigo da entrega. "Quero 
como poder pegar com a mão a palavra. A palavra é objeto? E aos instantes eu lhes tiro o sumo da fruta." (LISPECTOR, 1998a, p. 12).

Para Cixous, esse pegar a palavra com a mão é o movimento de descida dos três degraus na escada da escritura, saindo da linha do horizonte em direção à profundeza das raízes. Cixous se firma nas vivências de A paixão segundo GH (LISPECTOR, 1998b), texto no qual a própria Clarice sente as prescrições do Levítico: são Those-Bible e suas opiniões que é preciso deixar de lado a fim de lançar-se na experiência: Água viva é com certeza a feitura clariceana mais radical em termos da liberdade na criação de uma ambiência de escritura que se situa fora do horizonte de expectativa de Those-Bible. Como não-livro, o texto não oferece uma trama, personagens definidas, tempo e espaço reconhecíveis e quaisquer das outras marcas características que Aristóteles elencou na Poética. Subvertendo a escritura convencional, rompendo com as regras da narrativa, essa busca do it, a captura do instante sem forma, exemplifica o cruzamento a que Cixous convida nas suas três lições, um atravessar as bordas do adequado, uma visita sem medo à escola dos Mortos, uma vivência de Sonhos e a descida até as Raízes. Em Água viva a narradora chega mesmo a dedicar-se inteiramente às flores por um longo trecho de vivência e compreensão das diversas formas de delicadeza que elas encarnam - este interesse pelas flores é o ponto que Cixous levanta no final do seu percurso. Tudo acaba em flores, na observação sensível de seus detalhes, na fruição do seu frescor colorido: quem entrou pela escada dos Mortos deverá atingir o estado flor quando chegar ao seu ápice. O estado flor é uma das tentativas que a narradora de Água viva empreende em busca do it.

O it e o estado descrito por Cixous em suas três lições são assim próximos e aqui se envolvem em uma mesma aura: a da passagem, passagem para além de um limite preciso e prescrito; seja este o moral de Those-Bible, ou o do tempo, da imagem visual, da sanidade, do livro ou da morte. Todos esses itens se referem a fronteiras, zonas de passagem que operam conceitualmente nessa poética do limite como elementos a serem superados.

Esse cruzamento, essa passagem para além de limites não devem ser interpretados como fuga, rebeldia ou desconforto social/ideológico, mas sim como a sofisticada elaboração conceitual de um processo e um pensamento comum a muitas autorias contemporâneas. As obras do século XX a que me refiro nos irão possibilitar um entendimento do que é o escrever e de uma voz literária do nosso tempo. Em suas sutilezas, na elaboração cuidadosa e delicada de Cixous, podem ser lidos elementos capazes de lançar as bases para o entendimento da criação artística tal como esta se nos apresenta hoje possível. Isto porque Cixous fala desde 
um ambiente conceitual que já enfrentou os desafios do pós-estruturalismo, da arte contemporânea, da poesia marginal e do pós-tudo; com as aberturas possibilitadas por tessituras sobre a crítica, a verdade e a ciência que se mostraram suficientes para fundar um espaço aberto a contaminações, deslocamentos e derrocada de funções unívocas.

Autora, crítica e leitora a um tempo, Cixous vai fornecer um texto de teoria literária, depoimento de escritora e leitura crítica. Também Clarice oferece-nos uma novela que não se preocupa em enquadrar-se em um gênero definido, dispondo a linguagem de forma a deixar de lado as classificações. Em Cixous, referências pessoais, experiências de escritura estão unidas ao arcabouço teórico-crítico oferecido pela autora: são três lições para o aprendiz de escritor, o leitor, o estudante; são três interpretações do ato criativo, três teorias da escritura e a um tempo leituras críticas dos autores escolhidos. Assim também em Clarice temos um Água viva que é poesia, récit e novela; é um texto absolutamente híbrido no qual o instante é o tema central, levando a interlocuções constantes com a filosofia, a teologia e a história.

Quando Cixous elenca e cita suas preferências, não são apenas seus escritores favoritos e a interpretação pessoal que deles fez (apesar do estilo autobiográfico que está sempre colocado como melodia de fundo). São antes indícios a perseguir nessa trilha de uma descoberta a respeito do que é escrever, de como é possível escrever; calcada em experiências do século XX que nos levarão a um outro leque de possibilidades. Nesse sentido, interpreto aqui a fala híbrida da escritora como oferta de subsídios para uma formulação teórica, e por isso mesmo contaminada, a respeito do que é o processo criativo, a formulação mais adequada ao entendimento de Água viva.

\section{Uma tessitura de cadáveres}

A primeira seção do texto de Cixous se intitula "We need a dead (wo)man to begin". O escrever se funda em uma escola de cadáveres: é preciso deparar-se seriamente com a morte para inaugurar um ato criativo.

Essa asserção inicial é comum a variadas abordagens, e encontra ecos na teoria freudiana da sublimação. Algo que frustra, decepciona, faz falta: um vazio de não-vida motiva a autoria. Esse vazio é algo aproximado ao que afirma Lacan (2011, p. 498): são os buracos, as fendas e os vazios que continuamente exigem a criação de possibilidades, motivam atitudes, incitam à tentativa de completude, pois uma vez privados do Real, temos razões para busca-lo a vida toda e pelos mais exóticos caminhos. Dadas as diferenças e a relação de contiguidade entre as duas teorias, vê-se que essas abordagens psicanalíticas leem a ausência como estopim motivador: a morte da escola da escritura é algo com o qual começar, não é 
fim.

Julia Kristeva, em Sol negro, obra de 1987, também oferece uma brilhante compreensão das relações entre luto e sublimação. Posterior a Freud (cujo Mal-estar na civilização é de 1929-1930) e a Lacan (cujos Escritos partem de 1966), Kristeva é psicanalista e teórica da literatura que nos fornece uma leitura que passou pelos desafios do feminismo e dos conflitos do século XX. Ela constrói sua observação desde um espaço complexo e para nós mais próximo. Sua explanação sobre o ato criativo vem ao encontro da postura de Cixous. Não por acaso Adriana Cavarero (CAVARERO, 2011 p. 159-167) as aproxima em um comentário sobre as relações de parentesco entre as propostas de ambas. Em Sol negro, Kristeva enuncia: "Em lugar da morte, e para não morrer da morte do outro, eu produzo" (KRISTEVA, 1989, p. 96). Nada mais aproximado à noção de que precisamos de um(a) morto(a) para começar. Escreve Kristeva:

\footnotetext{
Quando pudermos atravessar nossas melancolias a ponto de nos interessarmos pela vida dos signos, a beleza também pode nos apanhar para testemunhar sobre alguém que, de forma magnífica, encontrou o caminho real pelo qual o homem transcende a dor de estar separado: o caminho da palavra dada ao sofrimento, até ao grito, à música, ao silêncio e ao riso (KRISTEVA, 1989, p. 97)
}

Cixous elenca variados exemplos: o de Thomas Bernhard com a frequentação do açougue, da torre escura, do cemitério; o de Poe com a morte da modelo de "O Retrato Oval"; o de Clarice com a esperança de que a vida da filha salvasse a mãe da morte. A morte está aí não apenas em casos individuais, depoimentos de escritores, temas de narrativas; mas como caminho descendente de transposição de um limite. A decepção inicial, essa sombra, esse fantasma, ícone mortuário, deverá estar no início. Clarice, em Água viva, escreve: "É o mínimo que posso fazer de minha vida: aceitar comiseravelmente o sacrifício da noite" (LISPECTOR, 1998a, p. 36). Esse sacrifício é o que vive nas profundezas do mistério, no inferno, que é visitado por aqueles que criam.

Segundo Cixous, "We go to the School of the Dead to hear a little of what we are unable to say" (CIXOUS, 1993, p. 53). É preciso cruzar a fronteira para, fora do limite, encontrar o indizível, o impossível; matéria, modo e motivo de criação. Escrever é, portanto, viver a morte sem morrer. É ter estado no lado de lá. Para além do maior risco. Na coragem de perder. $\mathrm{O}$ ato criativo é descrito por Cixous como esse aprendizado da morte, pois só quem não teve medo ganha essa possibilidade de criação: "It's learning not to be afraid, in other words to live at the extremity of life, wich is what the dead, death, give us." (CIXOUS, 1993, p. 10).

É no indizível que estanca nosso conhecimento: nessa fluência do it buscado por 
Clarice em Água viva. As palavras, no exercício de vibração que propõe a narradora, improvisam livremente a alegria de viver a passagem. Liberadas de fazer sentido, destituídas da atenção de Those-Bible, da necessidade de dizer com início, meio e fim; elas correm como instantes que pulsam sem plasmar-se em uma forma definida. São it, o exercício dinâmico dos dias.

\footnotetext{
Pois fui dormir e sonhei que te escrevia um largo majestoso e era mais verdade ainda do que te escrevo: era sem medo. Esqueci-me do que no sonho escrevi, tudo voltou par ao nada, voltou para a força do que Existe e que se chama às vezes Deus. Tudo acaba mas o que te escrevo continua. O que é muito, muito bom. O melhor ainda não foi escrito. O melhor está nas entrelinhas. (LISPECTOR, 1998a, p. 86).
}

Retorno portanto à primeira citação do livro de Clarice, do início do livro, para confrontá-la com esta da penúltima página. Toda a narrativa de Água viva é também reflexão sobre a possibilidade de escrever; registro e depoimento do ato criativo: depõe a favor da entrelinha, inexoravelmente colada à palavra, sendo em concreto uma experiência do cruzamento do limite, uma soltura radical da linguagem, um não-livro.

Essa violência de escrever é também uma insolência contra Deus, um alçar-se além dos limites da vida. A entrelinha é incapturável: é it, cola-se na palavra para misturar-se ao mistério.

\section{A memória que desafia Deus}

Pretendo agora continuar esse percurso descendente, que segue o emaranhado conceitual de Cixous, abordando uma autora não citada por ela, mas que apresenta em sua obra prerrogativas mais que suficientes para conquistar o possível (provável) amor da autora de Three steps on the ladder of writing. Impossível não sondar o que seria escrito por Cixous sobre Hilda Hilst. Hilst desenvolve um tema caro a Clarice e que está em Água viva no caroço dos questionamentos da narradora-pintora: existe Deus? Como ele pode existir sem alguém que o pensa e o cria? Chama atenção o fato de Clarice nomeá-lo muitas vezes "o Deus", tanto em Água viva quanto em outros trabalhos, geralmente com o artigo antecedendo-o, como que para aproximá-lo de nós.

$\mathrm{O}$ ato de escrever aparece em Hilst nos Poemas malditos, gozozos e devotos (2005) como insolência contra Deus. A morte está lá, como início, desde a primeira estrofe do livro: "Pés burilados / Luz-alabastro / Mandou seu filho / Ser trespassado" (HILST, 2005, p. 13). O corpo de Jesus vem encarnar uma complexidade de sugestões, das quais uma se sobrepõe, lido o conjunto dos poemas: Cristo é filho e também nós; quando ele é trespassado, segundo a tradição católica, seu sofrimento é o de todos nós. Da mesma forma, humano e divino vão 
entrar em múltiplas relações, superando as convenções nas quais o senso comum as compreende.

Esses poemas, desde o título, vão ter a um tempo a devoção e a malícia do gozo; a marca da carne, a fé e a subversão. Reinam desde sempre no país da abominação: são malditos, imundos. Hilst também aborda a derrelição em $A$ obscena senhora $D$ (HILST, 2001a), uma novela que, junto a Com os meus olhos de cão (HILST, 2001b), dá tônus de prosa a esse conjunto complexo de tensões entre o humano e o divino, o obsceno e a obediência às prescrições morais, o limite e o deslimite entre razão, subjetividade e loucura. Cixous cita a palavra "imundo", derivada do latim, que em francês semelha à nossa língua: $i$ mundo, fora do mundo. Os animais proibidos do Levítico, que estão fora da vida, cuja presença não é bem-vinda e que, ao toque, deixam o sujeito impuro, sendo este obrigado a lavar-se e lavar suas vestes, permanecendo impuro até a tarde...

Em Água viva há a constante tentação da impureza:

Como se arrancasse das profundezas da terra as nodosas raízes de árvore descomunal, é assim que te escrevo, e essas raízes como se fossem poderosos tentáculos como volumosos corpos nus de fortes mulheres envolvidas em serpentes e em carnais desejos de realização, e tudo isso é uma prece de missa negra, e um pedido rastejante de amém: porque aquilo que é ruim está desprotegido e precisa da anuência de Deus: eis a criação.

Será que passei sem sentir para o outro lado? (LISPECTOR, 1998a, p. 19)

A terceira seção do Levítico, "Instruções sobre o puro e o impuro", inicia com um capítulo dedicado a elencar os animais que se pode ou não comer. Entre os animais que ruminam, são proibidos o camelo, o hírace, a lebre, o porco: "Não podeis nem comer da carne deles nem tocar o seu cadáver; para vós eles são impuros" (Lv III, 11, 8). Também os bichos aquáticos e as aves recebem as instruções, sendo proibidas a águia, o urubu, a águia-marinha, o milhafre, os abutres, corvos, avestruz, a coruja, a gaivota, os gaviões, o mocho, o alcatraz, a gralha, a cegonha... "Esses animais vos tornam impuros - todo aquele que tocar o cadáver deles é impuro até a tarde, e todo aquele que carregar o cadáver deles deve lavar suas vestes e é impuro até a tarde" (Lv III, 11, 24-25).

Cixous frisa a ausência de uma explicação sobre as orientações do Levítico: suas regras são dogmas e não podem ser questionadas. A mim esse livro se torna interessante pela proximidade das práticas desses antigos judeus com a corrente religião de matriz africana que conhecemos no Brasil, que também resguarda em segredo e sob a beleza do mito a explicação dos rituais. Muitas práticas do Levítico parecem ter intuito de higienização e resguardo da proliferação de doenças, sendo a lepra e sua "purificação" diretamente abordada. Na leitura de 
Cixous, apoiada em um trecho de $A$ paixão segundo $G H$ (LISPECTOR, 1998b), o principal ponto que vem à luz é a imposição que o ritual religioso opera em relação aos fiéis. Estes, ignorantes das possibilidades de uma vida fora do sistema de ritos e proibições, têm seu cotidiano limitado pela regra inquestionável. Mais do que a sua prática costumeira, é limitado seu pensar: as balizas do dogma restringem a criação.

A temática bíblica fascina Cixous desde o ponto de vista de sua formação judaica; porém ela por várias vezes cita Jesus e os cristãos, estabelecendo interessantes análises paralelas e comparativas. Hilst cria a partir do seio mesmo da educação católica, com todas as culpas, ritos, desejos e proibições característicos dessa formação. A existência de Deus, o pecado, a finitude do homem, o ilimitado poder divino, a mortalidade como marca humana são temas recorrentes na construção de Hilst tanto quanto na de Lispector, cuja característica central é a superação dos limites entre esses temas. As barreiras do costume e da prática comum ganham tal frivolidade sob o gesto da escritura lenta e precisa, emaranhada dos mistérios de dentro. Assim, a narradora de Água viva diz ouvir música não com os ouvidos, porém sentindo a vibração da eletrola com as mãos. Não são as convenções do hábito que norteiam o modo de estar no mundo da personagem, e sim necessidades internas cuja regra não se conhece. Os poemas de Hilst, sendo poemas, negam a fé; sendo devassos, também reafirmam a religião, perfazendo o mesmo jogo.

Nos poemas de Hilst há um incessante diálogo entre fé, gozo, subversão e criatividade. Uma abordagem do processo criativo, do ato da escritura surge desse arcabouço de conceitos em constelação. Escolhi alguns poemas que dialogam diretamente com o meu percurso, observando que se podem tomar como fonte e sustentação de uma poética do limite. Inicio com o poema no qual a relação de dependência entre o ato criativo e o sono de Deus é anunciada:

V

Para um Deus, que singular prazer.

Ser o dono de ossos, ser o dono de carnes

Ser o Senhor de um breve Nada: o homem:

Equação sinistra

Tentando parecença contigo, Executor.

O Senhor do meu canto, dizem? Sim.

Mas apenas enquanto dormes.

Enquanto dormes, eu tento meu destino.

Do teu sono

Depende meu verso minha vida minha cabeça.

Dorme, inventado imprudente menino.

Dorme. Para que o poema aconteça. (HILST, 2005, p. 23) 
Leio aqui um embaralhamento entre a criação de Deus e a criação do homem, entre madureza e meninice, pecado e absolvição; um jogo que revela o estado no qual se encontra o poeta que, sendo homem, cria, tem em si um dos atributos divinos. Essa dualidade não passou incólume pelos teóricos medievais que procuravam conciliar arte e religião. Se Deus é o criador por excelência, não seria abominável a criação do homem? Contra o princípio da humildade iria a atitude da criatura que se coloca no lugar de Deus. E a criação livre, uma insolência. Foi somente sob o pretexto de seu caráter pedagógico que a arte foi disseminada dentro das igrejas, após múltiplas controvérsias e a famosa postura defensiva do papa Gregório. Deste contexto de conflitos emergem as notas não convencionais do eu lírico de Hilst. O homem poeta é Deus, e Deus sendo Deus reina no homem: dentro da carne, nos ossos, mistério sempre reafirmado. Então o homem é Deus e Deus é homem. Clarice também trama sonho e Deus:

Esta noite - é difícil te explicar - esta noite sonhei que estava sonhando. Será que depois da morte é assim? O sonho de um sonho de um sonho de um sonho?

Sou herege. Não, não é verdade. Ou sou? Mas algo existe.

Ah viver é tão desconfortável. Tudo aperta: o corpo exige, o espírito não pára, viver parece ter sono e não poder dormir - viver é incômodo. Não se pode andar nu nem de corpo nem de espírito.

Eu não te disse que viver é apertado? Pois fui dormir e sonhei que te escrevia um largo majestoso e era mais verdade ainda do que te escrevo: era sem medo. Esuecime do que no sonho escrevi, e tudo voltou para o nada, voltou para a Força do que Existe e que se chama às vezes Deus.

Tudo acaba mas o que te escrevo continua. O que é bom, muito bom. O melhor ainda não foi escrito. O melhor está nas entrelinhas. (LISPECTOR, 1998a, p. 86)

Sono, sonho, Deus e a criação estão portanto interligados tanto em Lispector quanto em Hilst. Lá, há um sono de Deus, necessário à feitura do poema: também no sentido subversivo da criação. Deus tem de fechar seus olhos para que o homem crie, explore a maior liberdade: Ele, o Onipresente, que sabe tudo e tudo vê. Mas a narradora de Clarice também evoca o sono para a criação, esta que vem de Deus e que pode cessar durante a vigília. Porém nunca cessa.

\author{
Poderia ao menos tocar \\ As ataduras da tua boca? \\ Panos de linho luminescentes \\ Com que magoas \\ Os que te pedem palavras? (HILST, 2005, p. 34-35)
}

Neste trecho do poema IX lemos novamente o conflito entre homem e Deus encarnado na palavra poética. A finitude do homem é reafirmada: somos um ínfimo que deseja a boca para falar. No entanto, é em nossa carne decrépita que se dão os desígnios de 
Deus, é aí que Ele mora. O ato criativo é desejo de parecença com a divindade, desejo de possuir-se na língua, esse instrumento de poder e posse. Castigo e renúncia são momentos da luta do poeta que espera Deus dormir para criar. Ou que dorme enquanto escreve. O Deus ausente nesse sono é também aquele que precisa do homem para imperar:

\author{
XVII \\ Penso que tu mesmo cresces \\ Quando te penso. E digo sem cerimônias \\ Que vives porque te penso. \\ Se acaso não te pensasse \\ Que fogo se avivaria não havendo lenha? \\ E se não houvesse boca \\ Por que o trigo cresceria? \\ Penso que o coração \\ Tem alimento na Ideia. \\ Teu alimento é uma serva \\ Que bem te serve à mão cheia. \\ Se tu dormes ela escreve \\ Acordes que te nomeiam. \\ Abre teus olhos, meu Deus, \\ Come de mim a tua fome. \\ Abre a tua boca. E grita este nome meu. (HILST, 2005, p. 53)
}

O sono do Senhor é também devoração: Deus precisa das palavras escritas pela sua serva. Para existir. Para ser Deus. Para falar. A fome que mora no meu corpo, apertada, e me instiga a escrever, é de Deus, da minha renúncia a Deus: come seu próprio sono, grita meu nome quando falo contra Ele. A referência à Ideia não deixa de sugerir nuances platônicas, pagãs, ou da interpretação medieval que se fez de Platão conciliando-o com a religião católica. Sou também Ideia pois participo, em minha decadência, da magnificência da eternidade. Uma dialética controversa surge da leitura do poema, que de tanto misturar Deus e o homem anula os limites que tradicionalmente damos a essas duas noções, a essas duas formas de existir; mesma dialética operada pela narradora de Água viva em busca do it e contra o fazer sentido comezinho do cotidiano. Ambas autoras perscrutam Deus no corpo e na fala criativa; ambas deitam fora as hierarquias professadas pelas religiões, ambas localizam seu poetar na Força maior porém não a consideram a partir da norma, e sim como consequência de um profundo conhecimento do corpo.

No poema XIII de Hilst, podemos ouvir a voz de Deus afirmando "Sou tudo isso, oco moita / E a serpente de versos da tua boca" (HILST, 2005, p. 43). Deus mora então nesse vazio e é Ele também a fala poética: a interdependência, o movimento recíproco que vai do humano ao divino, do gozo ao sofrimento crítico, da subversão à magnitude. 
Hilst contribui para a poética que persigo desde Clarice com uma indicação desse complexo desafio a Deus que corresponde à escrita, um desafio que vem somar à descrição das prescrições de Those-Bible, tornando-as mais claras e também ricas de detalhes e possibilidades.

Ler Lispector junto a Hilst reilumina ambas as autorias. O escrever está relacionado à morte e também a Deus; transborda para além dos limites da vida, do tempo, do visível, da organização social e também da finitude humana. Escrever nos imiscui nessa zona de risco a que chamamos Deus, porém não cabe nas definições estritas que recebemos das religiões.

\footnotetext{
A densa selva de palavras envolve espessamente o que sinto e vivo, e transforma tudo o que sou em alguma coisa minha que fica fora de mim. A natureza é envolvente: ela me enovela toda e é sexualmente viva, apenas isto: viva. Também eu estou truculentamente viva - e lambo o meu focinho como o tigre depois de ter devorado o veado. (LISPECTOR, 1998a, p. 23)
}

A permanência da alma em seu corpo, em sua família, em sua rede de prescrições, já não é possível: a escritura ultrapassa todas essas classificações para, livre do limite, se fazer a si mesma. Cixous, leitora de Clarice, esclarece com os seus degraus da morte e dos sonhos a linha que chegará exatamente às raízes, estas que compõem a selva de palavras de Água viva, experiência radical com a linguagem que inaugura pensamentos através da subversão das categorias definidas das separações costumeiras que encontramos nas classificações da cultura ocidental. É um jogo que, embebido de múltiplas referências, porém correndo todos os riscos inerentes à escritura, chega a construir um outro modo de estar e sentir o mundo, desafiando Deus, a natureza, a linguagem através da morte, do sonho e de um contato íntimo com as raízes.

\section{Lady Lazarus}

A filósofa italiana Adriana Cavarero (CAVARERO, 2011, p. 168-180) comenta a voz de Cixous em proximidade com a de Kristeva, afirmando que aquela apresenta o prazer da escrita liberado das normas paternais. Interessada na compreensão de um prazer vocal e sua defesa contra um "logocentrismo grafocêntrico", Cavarero lança sua ênfase sobre as sonoridades dessa escritura feminina feita com o corpo, languelait no termo cunhado por Cixous. Uma mãe-língua cujas sonoridades aprazíveis podem ser apreciadas pelos ouvidos. A escritura que é possibilidade de vivenciar o corpo da mãe, retornando à liberação prévia à entrada no simbólico, na lei paterna, no regime de prescrições e regras que lemos no Levítico. Those-He-Bible é um sistema complexo que inclui tanto a exclusão do prazer vocal quanto o cerceamento do corpo, limites que a escritura clariceana ultrapassa. 
Para concluir minhas observações para essa poética do limite calcada nos três degraus de Cixous, penso em oferecer um breve comentário acerca do poema "Lady Lazarus", de Sylvia Plath.

O nome "Lázaro" aparece no Novo Testamento em vários momentos, dos quais eu gostaria de ressaltar dois: o da parábola do pobre e do rico e o do homem ressuscitado por Jesus. Dentro das proezas narradas nos quatro evangelhos que compõem o Novo Testamento, há muitas curas de doenças: cegos que começam a ver, coxos que caminham, tudo sob o efeito das mãos de Jesus. Entre essas proezas, há que se ressaltar a que acontece com Lázaro, morto em vias de ser sepultado que o Cristo traz novamente à vida.

Além dessa personagem, há o Lázaro mendigo que procurava alimentar-se todos os dias dos restos que caíam do banquete do rico. Ao chegar à espiritualidade (cruzar o limite da vida), esse mendigo estava nos altos do Paraíso, enquanto que o rico estava no inferno. Ele simboliza então o morto que retorna à vida em vários sentidos: após a passagem, o que há é um Lázaro reconfortado, elevado, reconstituído. Tendo visto o inferno em vida, ele pode agora lançar-se às belezas da vida eterna.

O poema de Sylvia Plath parece-me o fechamento perfeito para a descida proposta por Cixous, até as raízes, até as flores, até o lado de lá. Lázaro é a imagem daquele que volta à vida tendo conhecido a morte. Escrever é vivenciar a morte sem morrer, é permear-se de um conhecimento que só quem ultrapassou o limite pode acessar. Lady Lazarus é a negação de Those-Bible, o cruzamento de um limite, a ousadia professada. Sempre retorna, incorrigível. Fornece aos convivas o espetáculo do seu aparecimento quando todos a julgavam sem volta:

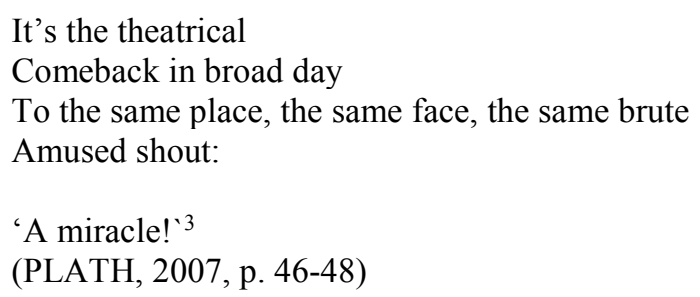

Nessa dialética do criar para devorar-se, matar-se para viver, o poema Lady Lazarus é metáfora da criação que complementa e encerra as características de todo esse percurso. A fala poética é essa sempre ressuscitada: aquela que retorna após a morte, refazendo-se a cada década, recriando o mundo e as coisas com essa palavra que, mais do que veículo, é coisa em si mesma. 3 "É o teatral / Regresso em plena luz do sol / Ao mesmo local, ao mesmo rosto, ao mesmo grito / Aflito e brutal:
// "Milagre!"”. Tradução de Rodrigo Garcia Lopes e Maria Cristina Lenz de Macedo. (PLATH, 2007, p. 47-49). 
Sou-me.

Mas há também o mistério do impessoal que é o "it": eu tenho o impessoal dentro de mim e não é corrupto e apodrecível pelo pessoal que às vezes me encharca: mas seco-me ao sol e sou um impessoal de caroço seco e germinativo. Meu pessoal é húmus na terra e vive do apodrecimento. Meu "it" é duro como uma pedra-seixo. (LISPECTOR, 1998a, p. 28)

Há que morrer para ressuscitar, devorar-se no mistério, ver o outro lado e voltar à vida, lazarianamente - este é o ato da escritura. O poema Lady Lazarus de Plath também é testemunho sobre esse processo criativo, perfazendo com seu ritmo a liberdade que o rompimento com o limite aufere. Seja em um suporte ou outro, dentro das artes literárias ou musicais, como bordado ou escultura, como texto datilografado ou cantado: é a mesma movência anunciada nos três degraus de Cixous. Há muitas relações entre Clarice e Plath no que toca Água viva e Ariel, desde a "aleluia" inicial da narrativa e a canção da manhã do nascimento até o encarar da morte como desafio de escrita e o retorno lazariano da palavra que é "it".

\footnotetext{
Estou prestes a morrer-me e constituir novas composições. Estou me exprimindo muito mal e as palavras certas me escapam. Minha forma interna é finamente depurada e no entanto o meu conjunto com o mundo tem a crueza nua dos sonhos livres e das grandes realidades. Não conheço a proibição. E minha própria força me libera, essa vida plena que e me transborda. E nada planejo no meu trabalho intuitivo de viver: trabalho com o indireto, o informal e o imprevisto.

Agora de madrugada estou pálida e arfante e tenho a boca seca diante do que alcanço. A natureza em cântico coral e eu morrendo. (LISPECTOR, 1998a, p. 37)
}

A narradora de Água viva é, como o eu-lírico do poema de Plath, um Lázaro que se posiciona, no mundo oculto, ao contrário do que foi na terra, mexendo com as hierarquias, bem como um Lázaro que, tendo conhecido a noite, retorna para o cântico da aleluia incólume. Porque através da palavra essa passagem não apenas desconhece obstáculos como também é o movimento natural. A cobrança do corpo, da passagem do tempo, da situação social, da finitude e dos outros aspectos que elenquei acima há de retornar como morta-viva, tece seu movimento no ritmo do canto. É antes a cobrança de uma fala poética que está sempre em vias de se consolidar, operando nos limites, lidando com os riscos. Conforme Cixous, "The only book that is worth writing is the one we don't have the courage or strength to write" (CIXOUS, 1993, p. 32). Para descer os degraus, é preciso deixar de lado o medo, lançar-se na aventura seriamente, negando o que nos torna semelhantes a Those Bible, àqueles que têm "a terrível limitação de quem vive apenas do que é passível de fazer sentido" (LISPECTOR, 1998a, p. 20).

A busca do "it" é uma operação idêntica à da Lady Lazarus que ciclicamente morre e nasce: "Mas há os que morrem de fome e eu nada posso senão nascer." (LISPECTOR, 1998a, 
p. 40) Ao chegar às raízes, a essa matéria densa que é a própria matéria do "it”, chega-se à terra através do verbo: "Conheço um modo de vida que é sombra leve desfraldada ao vento e balançando leve no chão: vida que é sombra flutuante, levitação e sonhos no dia aberto: vivo a riqueza da terra” (LISPECTOR, 1998a, p. 63). A escritura, que segundo Cixous deve passar por esses mesmos estágios de morte, sonho e terra, é então também uma forma de leveza, rica como a própria matéria da qual nascem as flores, os frutos. Raízes que, ocultas, não deixam de ser asa, pois levam à leveza das palavras fluindo sem cessar de seu "it" sempre buscado.

Percebo que chego ao final desse texto, eu também, com uma pandorga na mão. Como os escritores escolhidos por Cixous escolheram as flores em seus dias terminais, bem como Clarice em Água viva faz seu adaggio para cada flor, eu escolho aqui a pandorga que voa sem limites: desfaz raízes, incorporando esse processo que descende para depois liberá-lo. Então após a descida, só me resta descer para cima, observar essa pandorga que surge em minha mão e cruza o céu distraidamente, levada pela brisa. Procurei seguir uma poética do limite a partir de Cixous, costurando conceitos e procurando justificativas; porém na coerência com ela vejo que conceitos nunca bastam e justificativas não há: há uma palavra comendo-se letra, a entrelinha capturada na forma concreta, a matéria bordada desafiando a morte. O que há é nossa polêmica a respeito do que é puro e impuro, e nossa necessidade de superá-los para compreender a fulgurância e o infinito em uma maçã. Uma maçã que, indo ao encontro das raízes, não nega a luz: é maçã no escuro que vê, e vê plenamente: ousa o instante, vive o it, encontra a água viva das palavras que nutrem.

\section{Referências}

BRANCO, Lucia Castello. "Palavra em ponto de p". In: Edições de bolso, 1998, p. 33-47.

. Coisa de louco. Sabará:

CAVARERO, Adriana. Vozes plurais: filosofia da expressão vocal. Belo Horizonte: Editora da UFMG, 2011.

CIXOUS, Hélène. Three steps on the ladder of writing. Tradução do original francês de Sarah Cornell e Susan Sellers. Nova Iorque: Columbia University Press, 1993.

FREUD, Sigmund. O mal estar na civilização. Rio de Janeiro: Imago, 1997.

HILST, Hilda. Poemas malditos, gozosos e devotos. São Paulo: Globo, 2005.

. A obscena senhora D. São Paulo: Globo, 2001a.

. Com os meu olhos de cão. São Paulo: Globo, 2001 b.

. Poesia (1959/1979). São Paulo: Quíron/INL, 1980. 
KRISTEVA, Julia. Sol negro: depressão e melancolia. Rio de Janeiro: Rocco, 1989.

LACAN, Jacques. A instância da letra no inconsciente ou A razão desde Freud. Tradução de Inês Oscki-Depré. In: . Escritos. São Paulo: Perspectiva 2011, p. 496-529.

LISPECTOR, Clarice. Perto do coração selvagem. Rio de Janeiro: Rocco, 1998.

. Água viva. Rio de Janeiro: Rocco, 1998a.

. Laços de família. Rio de Janeiro: Nova Fronteira, 1983.

. A paixão segundo GH. Rio de Janeiro: Rocco, 1998b.

. A maçã no escuro. Rio de Janeiro: Nova Fronteira, 1982.

NUNES, Benedito. O dorso do tigre. São Paulo: Editora 34, 2009.

PLATH, Sylvia. Ariel: edição restaurada e bilíngue, com os manuscritos originais. Tradução de Rodrigo Garcia Lopes e Maria Cristina Lenz de Macedo. Campinas: Verus Editora, 2007.

SANTIAGO, Silviano. A aula inaugural de Clarice Lispector. In: . O cosmopolitismo do pobre: crítica literária e crítica cultural. Belo Horizonte: Editora da UFMG, 2008, p. 231240 .

SCHWARZ, Roberto. Perto do coração selvagem. In: ensaios críticos. Rio de Janeiro: Civilização Brasileira, 1965, p. 53-57. A sereia e o desconfiado:

[Recebido em 29 de janeiro de 2016 e aceito para publicação em 29 de abril de 2016]

\section{: Writing as medusa}

Abstract: In this paper I'll offer a personal reading of the short novel Água viva (medusa, or "living water", in Portuguese) from Clarice Lispector, through Helène Cixous statements about the creative process which she explains in her book Three steps in the ladder or writing. Cixous creates the image of a descendent ladder that has three steps: death, dreams and roots. Lispector does the same movement searching her "it", and composes a radical practice with language that is also an investigation. In order to follow this path of the descendent ladder and analyze the "it" through comparative reading, I'll bring some of Hilda Hilst's poems, from her book Poemas malditos, gozozos e devotos and also Sylvia Plath's, from Ariel, namely "Lady Lazarus". Hilst constructs a game between obedience and subversion, faith and poetic creation, proposing a complexity of images from the idea of God, transfigured. Plath already brings to the reflection the cyclic recurrence, which is also a kind of all fear letting go. The readings of Hilst and Plath give light, in its own way, to the route undertaken in Cixous trail and enrich the search of the Lispector's "it".

Keywords: Lispector. Cixous. Poetry. Composition. Death.

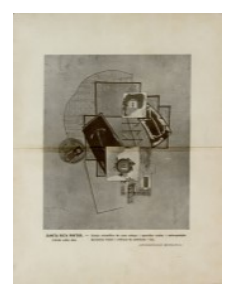

